\title{
A hard-boiled krimi lehetôségei Magyarországon (Kondor Vilmos: Budapest noir, Gárdos Éva: Budapest noir)
}

\begin{abstract}
Absztrakt
Tanulmányunkban Kondor Vilmos Budapest noir címû́ regényét (2008) és Gárdos Éva Budapest Noir (2017) címú filmjét elemezzük a hard boiled krimi és a film noir múfaji hagyományainak meghonosíthatósága szempontjából. A zsánerkérdést mindkét esetben a lokalizációs technikák és a térkezelés problémájára szúkítjük. A tanulmány elsô részében felvetjük a hard-boiled vagy kemény krimi és a film noir közötti folytonosság kérdését, hogy a második részben a két fókuszált szövegelemzés segítségével a múfaji minták késôi adaptálásának jelenségét vizsgáljuk meg. Következtetésünk az, hogy Kondor regénye a múfaji minta kritikai, Gárdos filmje pedig a múfaji minta nosztalgikus adaptációját adja.
\end{abstract}

\section{Szerzó}

Kálai Sándor (1974) médiatörténész. A Debreceni Egyetem Kommunikáció- és Médiatudományi Tanszékének docense. Kutatási témája a tömegkultúra története, különösen a krimi intézményesülése. Számos, a populáris kultúra részjelenségeivel kapcsolatos nemzetközi projektben vett részt, a Littératures Populaires et Culture Médiatique szervezet tagja. Résztvevôje a DETECt. Detecting Transcultural Identity in European Popular Crime Narratives elnevezésú, négyéves futamidejú nemzetközi projektnek.

Keszeg Anna (1981) kultúrakutató. A Debreceni Egyetem Kommunikáció- és Médiatudományi Tanszékének, valamint a Babeș-Bolyai Tudományegyetem Kommunikáció-, Közkapcsolatok és Reklám Intézetének adjunktusa. A kolozsvári Babeș-Bolyai Tudományegyetemen, a párizsi Sorbonne Paris IV-on és az École des Hautes Études en Sciences Sociales-on, valamint a budapesti Eötvös Loránd Tudományegyetemen tanult. Tagja a DETECt. Detecting Transcultural Identity in European Popular Crime Narratives elnevezésû, négyéves futamidejű nemzetközi projektnek.

https://doi.org/10.31176/apertura.2019.14.4.1 
Kálai Sándor - Keszeg Anna

\section{A hard-boiled krimi lehetôségei Magyarországon (Kondor Vilmos: Budapest noir, Gárdos Éva: Budapest noir)}

Történelmileg a Rossz uralkodik. A rossz uralma társadalmi és politikai. A társadalmi és politikai hatalom gazemberek kezében van.

(Jean-Patrick Manchette 2003: 20)

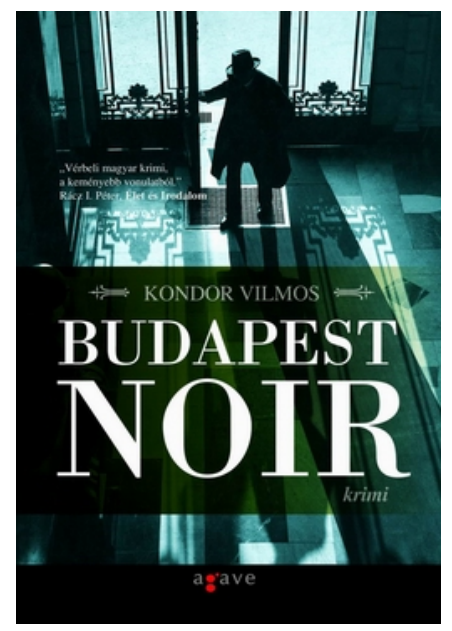

A regény boritója 
Hosszú elemzést igényelne annak bemutatása, hogy milyen sorsa lett Magyarországon az amerikai eredetú, az 1920-as és 1930-as években ott meggyökeresedô és nagyon hamar transzmediális sikereket arató hard-boiled (vagy kemény, vagy noir) kriminek ${ }^{[1]}$. Egyfelól látnunk kell azt, hogy a krimi múfajának honi története is szövevényes (Kálai 2014), hiszen a politikai, kulturális és irodalmi folyamatok miatt többször is újraintézményesül (gondolhatunk itt például az 1945 utáni vagy pedig a rendszerváltást követô folyamatokra). A hard-boiled csak részlegesen juthatott el Magyarországra születése éveiben, bár megjelent magyarul Hammett két (The Maltese Falcon és The Thin Man) és Cain egy (The Postman Always Rings Twice) regénye, de ez nyilván nem volt elég a számottevố hatás kifejtéséhez, mint ahogy az sem, hogy néhány magyar szerzó is kísérletezett a múfajjal: Grób László könyvében (Grób 2015: 22-28.) felsorol néhány szerzôt és regénycímet, amelyek a kemény krimi magyar reprezentánsai lehetnek. A búnügyi regény maga csak a hatvanas évek második felétôl jelenik meg újra Magyarországon, jórészt fordításokon keresztül, s egészen a 2000-es évek elejéig kellett várni arra, hogy magyar szerzố tollából szülessen hard-boiled krimi. [2] 


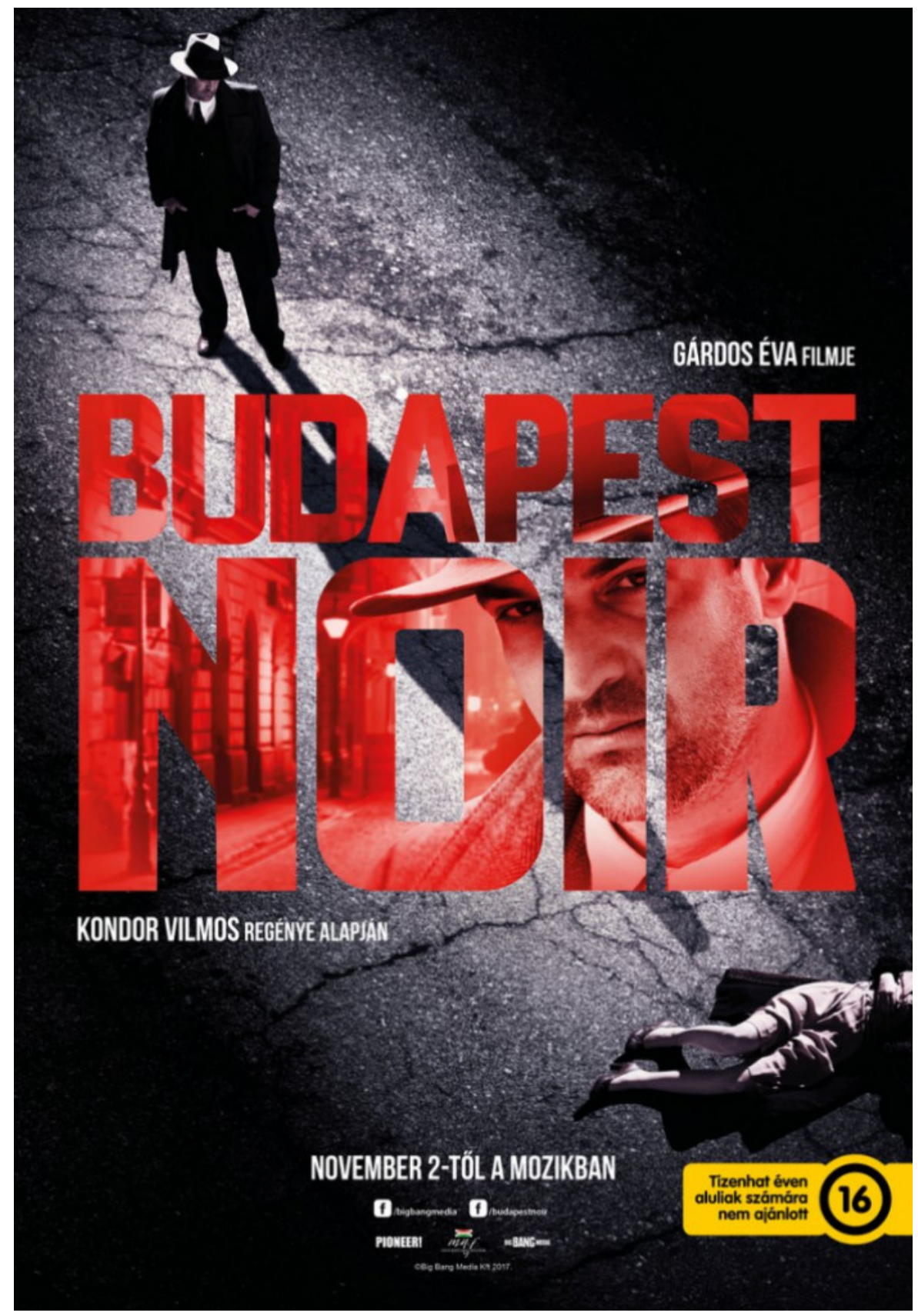

\section{A film plakátja}

Ugyan a film noir és a hard-boiled közötti filiáció nyilván bonyolultabb az egyszerú hatásnál, az nem tagadható, hogy az irodalmi és a filmes múfajt sok szál köti össze (Mayer 2007): született könyv arról, hogyan filmesítették meg Chandler regényeit (Philips 2000), a két más-más mediális közegben alakuló múfaj közötti viszonyról (Irwin 2006), de egy kurrens, általános áttekintést adó elemzés sem felejti el hangsúlyozni az irodalmi múfaj filmre kifejtett hatását (Dickos 2002: 96-155.). A filmes múfajról tengernyi elemzés született már, csakúgy mint a múfaj idôbeli és térbeli kiterjedéséról/kiterjeszthetôségéról (ez utóbbihoz, vagyis annak a kérdéséhez, hogy mit tekinthetünk nemzetközi noirnak, ld. Fay-Nieland 2010, elsősorban a negyedik fejezetet és Broe 2014). Messzire vezetne e kérdés, vagyis a kiterjeszthetôség részletes elemzése, s ennek kapcsán 
annak felvetése, hogy létezik-e magyar film noir. Az 1931 és 1944 közötti időszak magyar búnügyi filmjeit tekintve Lakatos Gabriella félbûnfilmrôl beszél: politikai, cenzurális és gyártástechnikai okok miatt a bün megmutatása problematikus az adott korszakban (Lakatos 2013: 51). A szerzô elkülönít egy filmcsoportot, amelyet noir-melodrámaként aposztrofál, így egy késôbb megjelenô múfaji terminust alkalmaz olyan filmekre, amelyek a múfaji jelölő megszületése elôtt, 1936 és 1944 között készültek.

\section{Fordítható-e film noirrá a kemény krimi?}

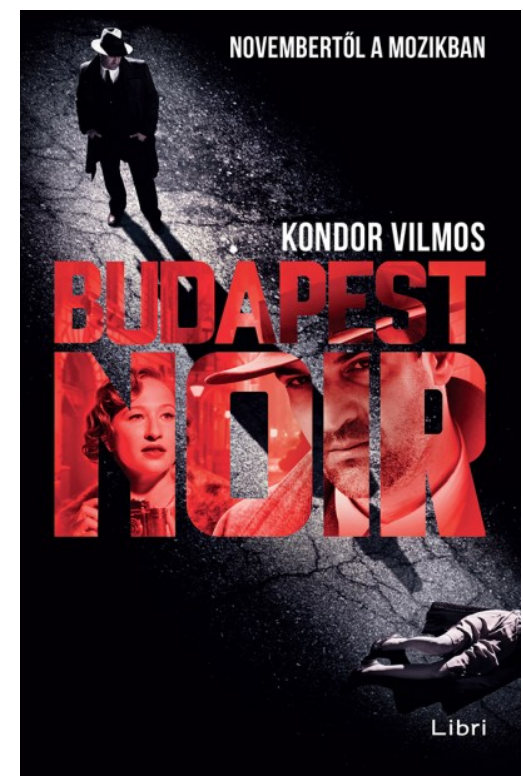

Az új kiadás boritója

A magyar film szövevényes történetét tekintve könnyen lehet tehát, hogy az, amit Gárdos Éva hajt végre a film médiumában, megfeleltethetô Kondor irodalmi gesztusának. ${ }^{[3]}$ Ugyan a múfajok ( hard-boiled krimi és film noir) már régóta jelen vannak a magyar kulturális palettán (elsôsorban importált termékek, regények és filmek formájában), de ha abból az elôfeltevésbool indulunk ki, hogy egy múfaj akkor létezik, ha tudatában van önmaga létének, vagyis intézményesült mivoltának (Reuter 1999), akkor mind a hard-boiled, mind a noir - elegendó hazai példa híján még csak a kezdô lépéseknél tart.

Bármiféle múfaj esetében tehát szükségesnek látszik az önmagához való reflexív viszony tételezése: ennek van textuális (tematikus, narratív formák visszatérése) és társadalmi dimenziója (a múfajra jellemzô produkciós és recepciós logikák megszilárdulása) (Reuter 1999). S mindez még fontosabbnak tûnik akkor, amikor egy múfaj más kultúrában (tehát kulturális változatként) kezd el létezni, ráadásul jóval késôbb, mint ahogyan megjelent - ez a helyzet tehát szinte eleve kódolja a reflexív viszonyt. A tanulmány által vizsgált helyzetre alkalmazva: mi történik akkor, amikor Kondor Vilmos 2008-ban publikálja az elsô magyar hard-boiled regényt?

Jean-Patrick Manchette, az 1970-es és 1980-as évek egyik legnagyobb hatású francia krimiszerzője 
számára világos volt, hogy a krimi - amellett, hogy szerzôje számára komoly anyagi sikert jelenthet - olyan múfaj, amely nagyon érzékenyen képes egy adott társadalom problémáira reagálni. De saját korának francia krimije, a noir múfaj, a hard-boiled ersatz-aként gondolható el: „Megvolt az amerikai krimi kora. 1970-ben írni azt jelenti, hogy új társadalmi valósággal kell számolni, és azzal a ténnyel is, hogy a krimiforma meghaladott, mert elmúlt az ideje: egy meghaladott formát újra felhasználni azt jelenti, hogy referenciálisan használjuk, tiszteljük, miközben kritizáljuk, eltúlozzuk, minden oldalról eltorzítjuk. Még ha tiszteletben tartjuk, akkor is eltorzítjuk." (Manchette 2003: 18) Még ha Manchette kijelentése, amely minden bizonnyal nem mentes a korabeli, ún. „elit” irodalom elméleti belátásainak hatásától sem, túlzónak is túnhet, amit itt állít, az összekapcsolható a múfajtudat fogalmával.

Az alábbiakban erre keressük a választ: milyen (reflexív) múfaji viszony jellemzi a címben említett regényt és filmet? Az elemzések a kérdésre a regény és a film lokalizációs stratégiáit vizsgálva próbálnak válaszolni. Míg Kondor regénye problematizálja a múfajhoz való viszonyt, addig Gárdos Éva filmadaptációja inkább nosztalgikus kapcsolatot alakít ki a választott filmes hagyománnyal. Ugyanakkor mind a film, mind a regény úgy is viszonyra lépnek a múlttal, hogy történeti krimiként múködnek: mindkét történet világos történeti pillanathoz, 1936-hoz, Gömbös Gyula temetéséhez és az azt követô napok budapesti történéseihez kapcsolódik. Így a térkezelésen kívül lényegessé válik az a kérdés is, hogy mennyire történetiesítettek a budapesti terek, s múlthoz való viszonyukat milyen attitúd jellemzi. Zymunt Bauman 2017-es, utolsó kötetében azt diagnosztizálta, hogy a kortárs kultúra rögeszmésen múltorientált, a nosztalgia és a retró alakzatai uralják (Bauman 2017). A múlthoz való viszonynak e formái osztoznak abban a meggyôzôdésben, hogy az emberiség történetének jobb periódusait már magunk mögött és nem magunk elôtt tudjuk. Svetlana Boym óta azt is tudjuk, hogy a nosztalgiának két paradigmatikus múködésmódja van: a reflektív és a resztoratív. Míg a resztoratív nosztalgia újra kívánja éleszteni a múltat, az abban való elidôzést ígéri, a reflektív nosztalgia csak a múlt iránti vágyakozást ôrzi meg, tudatában van a múlt visszahozhatatlan voltának (Boym 2001: 41-57.). A múfajisághoz és a múlthoz való viszony a film és a regény esetében össze is kapcsolódik egymással: Kondornál a múfajtörténetre való reflexió a múltra való reflexió is egyúttal, Gárdos Évánál pedig a filmes hagyomány iránti nosztalgia a harmincas évekbeli Budapest kifinomult terei és tárgyi kultúrája iránti vágyakozást is feltételezi.

\section{Regény egy bünös városról}

Az írott elbeszélések esetében nagyon sokáig az idó reprezentációjának módja foglalkoztatta az elemzôket. Ám ahogyan az elbeszélés konfigurálja az idôviszonyokat, úgy mindez elmondható a térrôl is, ám mégis az ún. spatial turnre (Warf - Arias 2008, Tally 2012), a Michel Foucault, Michel de Certeau vagy Henri Lefebvre nevével fémjelzett teoretikus háttérre volt szükség ahhoz, hogy az irodalmi térkonfigurációk vizsgálata lendületet kapjon.

Mihail Bahtyin kronotoposz fogalmának lényege, hogy az idó és a tér szétválaszthatatlan, egymást 
kölcsönösen meghatározzák. ${ }^{[4]}$ Henri Mitterand tanulmányának (Mitterand 1990) egyik legfontosabb aspektusa az, hogy Bahtyin írásainak szisztematikus olvasásával javaslatot tesz a kronotoposz szintjeinek és formáinak elkülönítésére. Legáltalánosabb jelentésben a kronotoposz minden olyan emberi univerzumot jelent, amelyet konszubsztanciális módon határoz meg a tér és az idô - ez a kulturális kronotoposz. A múfaji kronotoposz arra utal, ahogyan egy adott múfaj az idô- és térösszefüggéseket kezeli: ebben az értelemben a regényt a konkrét tér és a történelmi idô jellemzi. Az adott múfajon belül múalkotások egy csoportja (almúfaja, pl. görög regény, kalandregény, pikareszk regény) is létrehozhat egy sajátos kronotoposzt: a lovagregényt a csodák világa és a kaland ideje jellemzi. A negyedik szintet az egyedi múalkotásokban megjelenô kronotoposz jelenti. Azonban a tipológiai szinten túl el lehet különíteni más tér-idô témákat, motívumokat: Bahtyin rendszerében ide tartozhat a találkozás cselekménysora, de akár az út, a balzaci regények egyik fontos tere, a polgári szalon vagy a kastély is - ez a tematikus kronotoposz. A hatodik szint pedig a világreprezentáció egyfajta modális kategóriáját jelenti: távolság, kiterjedés (a tér összetevô dominanciája) vagy növekedés (az idô összetevô dominanciája); Rabelais poétikáját például a növekedés és a hanyatlás ellentéte határozza meg. Elemzésünkben mi is hasznosítjuk ezeket a belátásokat, hiszen maga a nyomozás is a kronotoposz egyik (múfaji) változatának tekinthetô, lehetôvé téve egy sajátos tér- és időösszefüggés létrehozását.

Az 1990-es évek óta a fentebb említett térbeli fordulat eredményeként a geográfusok is élénk érdeklôdést mutatnak az irodalom iránt, olyan tudásformaként tekintve rá, amely segít megérteni az ember és a tér viszonyát. Az irodalomtudomány új területekkel bővült: a literary geography (Moretti 1998, 2005; Williams 1973), a geocriticsm (Westphal 2011) inkább a térbeli reprezentációk természetére koncentrálnak. Új megközelítési mód az ún. location studies, amely többek között két dán kutató, Kim Toft Hansen és Anne Marit Waade nevéhez kötődik, akik regények, filmek és sorozatok elemzésén keresztül tanulmányozzák a skandináv noir káprázatos sikerét (Hansen Waade 2017). A lokalizáció legtágabban úgy határozható meg, mint az a konkrét tér, amelyben egy jelenet vagy szekvencia egy adott audiovizuális vagy írott elbeszélésben lezajlik. A módszer alapfeltevése az, hogy egy adott múalkotás térbeli elemzését egyesíteni kell a háttérben múködô gazdasági logikával (könyv esetében a stratégia része lehet egy helyjelölố címbe helyezése, a termék adott helynek megfelelô marketingje vagy éppen a helyszín megváltoztatása a könyvpiac tendenciáinak megfelelóen, stb.; filmek, sorozatok esetében ide tartoznak a helyszínek, a díszletek megválasztására vonatkozó döntések). A lokalizációra vonatkozó kutatásokat élénken foglalkoztatja a nyilvánvaló és felismerhetố helyek iránti növekvố tendencia, amely a desztinációmarketinghez vagy a kulturális turizmushoz kapcsolódik, illetve a lokalizáció mint valósághatás, amely írott vagy audiovizuális elbeszélés által keltett hitelességérzetet teremt. Mélyebb szinten a helyek és a tájak összekapcsolhatják a helyet mint valóságeffektust, a helyet mint emléket és a helyalapú identitáskonstrukciókat (Hansen - Waade 2017: 53-76.). A location studies fố sajátossága a kulturális termékek térkonstrukciójának holisztikus megközelítése: az ezen a területen végzett kutatások többrétegú perspektívát alkalmaznak, különös tekintettel a helyekre mint társadalmi-politikai és földrajzi realitásokra, a helyekre mint kulturális konstrukciókra, valamint azokra a gazdasági és stratégiai érdekekre, amelyeket az ábrázolt terek jelenthetnek. 
Ebben a tekintetben ez az elemzési mód összekapcsolja a földrajzot az irodalommal és a filmmel, a közgazdaságtant az esztétikával, a turizmust a helyi identitással.

Kondor regényére áttérve: nyilvánvaló, hogy - mint ahogyan arról már volt szó - a bûnügyi regények legfontosabb strukturáló eljárása, a nyomozás kronotoposznak tekinthetô, és az idô-tér viszonyok kezelésének egy meghatározott módjára utal. Mivel történelmi búnügyi regényrôl van szó, a nyomozás kronotoposza mellett azonosítható egy másik, kulturális kronotoposz, az 1930-as évek Budapestjének reprezentációja lehetôvé teszi a történelmi idő és tér beírását a történetbe. A történet 1936 októberében, Gömbös Gyula miniszterelnök halála idején játszódik. Kondor legfontosabb újítása, ami egyben jelzi a múfajhoz való reflexív viszonyt is, hogy a történelmipolitikai kontextusnak megfelelően úgy dönt, hogy a nyomozó nem rendôr, hanem újságíró, Gordon Zsigmond, aki a kor egyik legfontosabb lapja, $A z$ Est bûnügyi riportereként dolgozik. Mobilis szereplő karakter, aki szakmai kompetenciájának megfelelóen jó nyomolvasó. Ez magyarázza, hogy a tematikus kronotoposzok egész sorát azonosíthatjuk, ilyen például az út (a város utcái), a találkozás (gyanúsítottakkal, tanúkkal, olyan szereplőkkel, akik információforrásként szolgálnak számára, és végül az elkövetôvel). Végül azonosíthatunk egy olyan aspektuális kronotoposzt is, a képzeletbeli világ ábrázolásának modális kategóriájaként, amely az 1930-as évek Budapestjét értelmezi: a város a veszély és a bûn tere. A kortárs olvasó tudja, hogy háború következik, amely elpusztítja a város terét és felfüggeszti a jövőjét. Kondor sorozata egy jól ismert és nagyon hatékony eljáráson alapul: azáltal, hogy a hôst saját városa terébe helyezi, az olvasó figyelme erre a térre is irányul. A bünügyi regény története azt mutatja, hogy se szeri, se száma az ilyen nyomozóknak: Maigret és Párizs, Fabio Montale és Marseille, Pepe Carvalho és Barcelona vagy Rebus és Edinburgh, Sherlock Holmes és London. Azon túl, hogy minden egyes alkalommal egy egyszerre autentikus (vagy legalábbis autentikusságra törekvô) és képzeletbeli város reprezentációját látjuk, ez a kapcsolat fordulópontot jelent a múfaj történetében: Eva Erdmann szavaival élve (2009) azzal, hogy egy történetet egy adott térben horgonyoz le, a múfajt egyfajta etnográfiai dimenzió is jellemzi. A sorozatok sikere - amelynek egyik jele az, hogy az olvasó a valódi városban a kitalált karakter lábnyomát keresi - kiaknázható a terek márkázása szempontjából is. 
Mint láttuk, a location studies-t az érdekli, hogy a narratívában milyen módon kerül ábrázolásra a konkrét tér. Ahhoz, hogy megértsük, hogy Budapest milyen lokációs elemként múködik, érdemes Hansen és Waade korábban idézett könyvében felvázolt osztályozási elvekhez fordulni. A képernyőn megjelenő elemek (on-screen features) „befolyásolják a hely megválasztását, valamint az ábrázolt couleur locale-t" (Hansen - Waade 2017: 68). Öt kulcsfontosságú elemet különböztethetünk meg e modell szerint: (1) part / szárazföld és sziget; (2) városi / vidéki területek; (3) éghajlat / idôjárás / szezonális változások; (4) infrastruktúra / mobilitás; és (5) építészet / múvészet / formatervezés (Hansen - Waade 2017: 68-73.). Bár a tipológiát a skandináv noir (és elsôsorban audiovizuális alkotások) tanulmányozására dolgozták ki, hasznos lehet azt Kondor regényére alkalmazni, mert a modell lehetôvé teszi, hogy megragadjuk Budapest, egy noir város sajátosságait - legalábbis, ahogyan az az elsố regényben megjelenik.

A város földrajzi elhelyezkedése ugyanolyan karakterisztikus, mint a skandináv területeké. A regényben a Duna a hagyományos szerepet tölti be: kettéosztja a várost, és két teljesen különbözô területet határoz meg. A fôszzereplô inkább Pestet kedveli: „Gordon továbbsietett. Nem szeretett Budán lenni. Valamiért Pest állt hozzá közelebb, ott legalább otthon érezte magát, már amennyire lehetett" (Kondor 2008: 111). Gordon tehát nem tud teljesen racionális magyarázatot adni választására, de az érzelmi okoknak következményei vannak: életének összes tere (lakása, barátnôje és nagyapja lakása, munkahelye) Pesten található, a körutak környékén, ez utóbbiak pedig a városi és kulturális modernitás emblematikus helyei. A magyar kulturális képzeletben kiemelkedô különbség van a Duna két része között, hasonlóan a Szajna két partja közötti különbségekhez Párizsban. Ez a megkülönböztetés egy gazdagabb, biztonságosabb Budán és egy prolibb, bizonytalanabb Pesten alapszik, amely idôbeli különbségeket is jelez: Pest nyitottabb a változásra, Buda pedig konzervatívabb. Gordon Pest-preferenciája jelzi, hogy együttérez a kiszolgáltatottakkal, és jobban kedveli a változó városi tájat. A bûncselekményt Pesten követték el, de olyan valaki áll mögötte, aki Budán lakik.

A hard-boiled krimi tipikus városi múfaj. A nyomozás során az elbeszélés Budapest társadalmi panorámáját is nyújtja, ahol az újságíró kapcsolódási pontként szolgál a társadalmi rétegek között. Vizsgálódásai során Gordon az arisztokrata rezidenciáktól a szegények külvárosi negyedeiig mindent bejár. A szereplôk a felsôbb osztályokat (gazdag budai polgárok, politikusok), a középosztályt (a szerkesztôségben dolgozó értelmiségiek, rendôrök), az alvilágot (prostituáltak, betörôk) képviselik. Gordon csak egyszer hagyja el a várost, amikor egy Miskolc melletti faluba megy, hogy találkozzon az áldozat volt szolgálójával. Ezen az egy epizódon kívül Gordon elmerül az utcák, sugárutak, külvárosok világában. A regény legelsố jelenete már tanúskodik a részletek iránti érdeklődésérôl, ez a város reprezentációjának legfontosabb eleme: Gordon „megitta a feketét cukorral, összehajtotta a Pesti Naplót, felállt, fizetett, feltúrte a gallérját, és kilépett a Rákóczi útra. A Blaha Lujza tér felé pillantott, látta a kiadóvállalat neonfényeit a távolban, majd benyúlt a zsebébe, elóvett egy cigarettát és rágyújtott" (Kondor 2008: 9), és hallja egy rikkancs hangját. A regény a város centrumában található szereplốt mutat, már cselekvés közben, akinek az érzékeit stimulálják a modern városi tér elemei (a fények, a zajok, a rikkancs hangja). Másfelól pedig már itt 
hangsúlyos az újság szerepe, nem csupán a hétköznapi emberek számára, akik elkapkodják a lapot, de elsôsorban Gordon, a bûnügyi riporter számára, mert csak a hivatása gyakorlásával képes a bûnösöket sarokba szorítani.

Az események 1936 októberében játszódnak, 6. és 15. között. Minden fejezet egy nap eseményeit meséli el, Gordon szemszögéból. Itt is megtaláljuk a hard-boiled egyik fontos „szabályát”: az éjszakai város reprezentációjának megfelelôen minden esôs, ôszi hangulatban történik, s ez a reprezentáció központi elemévé válik, utalva a várost és lakóit fenyegetô veszélyre.

Gordon egy Krisztinával, a barátnôjével folytatott beszélgetés során úgy foglal állást, hogy nem érdemes gépkocsit birtokolni Budapesten: „Különben is - tette hozzá Gordon -, nekem nincs idegzetem arra, hogy Pesten vezessek." (Kondor 2008: 127) Gordon gyakran utazik: vagy villamossal, vagy taxival (saját taxisofơrrel rendelkezik, aki elviszi az említett faluba), de gyalog is jár. Az autó elvágná ôt világtól; számára a várossal létesített közvetlen kapcsolat a fontos (tömegközlekedési eszközön soha nincs egyedül). Ez a közvetlen kapcsolat biztosíthatja szakmai sikerét, és ebben az esetben a nyomozás sikerességét is.

A (magán- és nyilvános) terek és Gordon velük fennálló kapcsolata is fontos aspektusa a regénynek. Gordon engedi, hogy hassanak rá az emberek, az elbeszélés a szerepló érzéki tapasztalatait is rögzíti, mindazokat az érzelmeket/érzéseket, amelyek az utcán sétálva vagy másokkal beszélgetve születnek. Gordon lakása (a Lovag utcában), nagyapja lakása (azon a téren, amely késôbb a Kodály körönd nevet kapja) vagy Krisztina (Lövölde téren található) lakása közel vannak egymáshoz, és az Andrássy út tengelyén vagy ahhoz közel találhatók. Gordon lakása nem tárgya részletes leírásnak, de Krisztina kortárs formatervezési trendek szerint berendezett otthonát Gordon szemszögéből látjuk, és a leírás egyben felfedi kapcsolatuk természetét is. Krisztina alapvetôen független nô, és saját tere ennek kifejezése:

Ugyan szeretett Krisztinánál lenni, a foteleket igencsak hiányolta. A nő ugyanis a legújabb enteriốrdivat szerint rendezte be kis lakását. Egyszerú ágy a sarokban, mögötte szekrény. Az ágy elôtt kétfedeles dohányzóasztal, rajra egy fehér hamutartó. Az ágy másik végében egy háromfiókos kisszekrény, tetején egy porcelánfigura, fölötte hosszú, díszítetlen keretben tükör. Amellett a tartón a lakás két növénye közül az egyik: egy cserepes virág, Gordon képtelen volt megjegyezni a nevét. A falon egyetlen absztrakt kép, ennyi. Krisztina még Berlinben szerette meg az új divatot, és gondosan ügyelt rá, hogy semmi ne törje meg a szoba egységét. Gordon nemegyszer szentségelt a fotel hiánya miatt, de Krisztinát nem érdekelte különösebben Gordon morgása. - A lakásában annyit ülhet azokban a lelakott fotelekben, amennyit csak akar - közölte, mire Gordon megvonta a vállát. (Kondor 2008: 25) 
A zsidó származású, de kikeresztelkedett családba született üzletember - aki akaratlanul lánya halálát okozza - Budán lakik, otthona furcsa benyomást kelt Gordonban - a lakás jelzi a családi feszültségeket:

Körbenézett. Nyilvánvalóan remek ízléssel rendezték be a házat, amely azonban egyáltalán nem volt otthonos. Minden csillogott, minden szép volt, elegáns. Átadta a lánynak a kabátját és kalapját, majd követte a nappaliba. Ugyanazt látta, mint a hallban. Drága, nehéz bútorokat, perzsaszônyegeket, biedermeier ülőgarnitúrát - amelyrôl gyanította, hogy eredeti - kristálycsillárt, Zsolnay vázát, brokátfüggönyt. Mintha egy múzeumban lett volna, vagy egy elegáns bútorboltban. Sehol egy személyes tárgy, sehol egy ránc a terítôn, sehol egy ottfelejtett könyv. (Kondor 2008: 121)

A privát tereken túl a Gordon foglalkozásához kötôdô terek fontosak: az újság szerkesztôsége, a kávéházak (ahol újságot olvas, ír, vagy barátaival találkozik). A búncselekmény a város központjában (Nagydiófa utca) történik, amit a rendôrség nem tud ellenőrzés alatt tartani.

A Budapest noir sikeres transzformációs múveletet hajt végre: átveszi a múfaj alapvetô jegyeit, de ezeket mai perspektívából a 30-as évek budapesti világához adaptálja. Gordon úgy tud leginkább a klasszikus magánnyomozókhoz hasonlítani (nemcsak életmódjában, hanem szakmai ethosát tekintve is), hogy nem magánnyomozó, nem rendôr, hanem újságíró. Krisztina alakján keresztül nem csupán a nôk helyzete, hanem a párkapcsolati dilemmák is felvázolhatók. Ugyanezt az adaptációs folyamatot látjuk, ha - amint azt itt tettük - a lokalizációs stratégiák felôl közelítünk a regényhez: a regényírót a hitelesség igénye vezeti, ugyanakkor a városreprezentáció, az éjszakai és bûnös Budapest megalkotása a múfaji sajátosságok alapján történik - a zsánerelemek alkalmazása és a rekonstrukcióra való törekvés termékeny feszültségbe kerül: a regény úgy illeszkedik a populáris irodalom kánonjába, hogy egyúttal történelmi összefüggéseket is problematizál. ${ }^{[5]}$

\section{Film egy bünös városról}




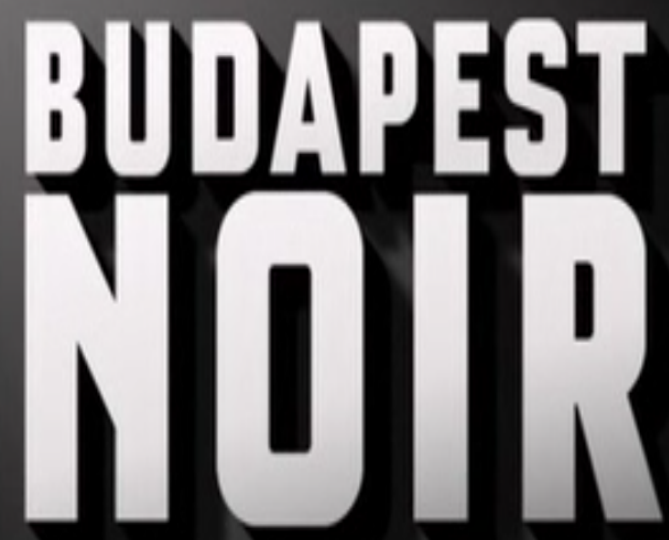

Budapest Noir (Gárdos Éva, 2017)

Budapest filmes megmutatásának sokféle hagyománya és sokféle tanulsága van: korszakonként és rendezőnként más-más városképet, más-más városvíziót jelenítenek meg a Budapesttel kapcsolatos filmek. ${ }^{[6]}$ A Budapest Noir esetében két tényezô kiemelten izgalmas: az elsô, hogy a film noir és a városi tér kapcsolata egy olyan zsánerösszefüggésben érthetô meg, melynek nagyon súrú filmtörténeti hivatkozásrendszere van, a második pedig, hogy feltételezi a politikai korrupció átszôtte város toposzát. Ugyanakkor a kronotoposz logikájába illeszkedôen indokoltnak látjuk feltenni azt a kérdést: milyen szerepet játszanak a terek a filmes médiumban, milyen típusai vannak a lokációhoz kapcsolódó jelentéseknek? A film helyszínei olyan térbeli struktúrát hoznak létre, mely konstruált filmes világ ugyan, de társadalmi, földrajzi és imaginárius valóságot mozgat. 


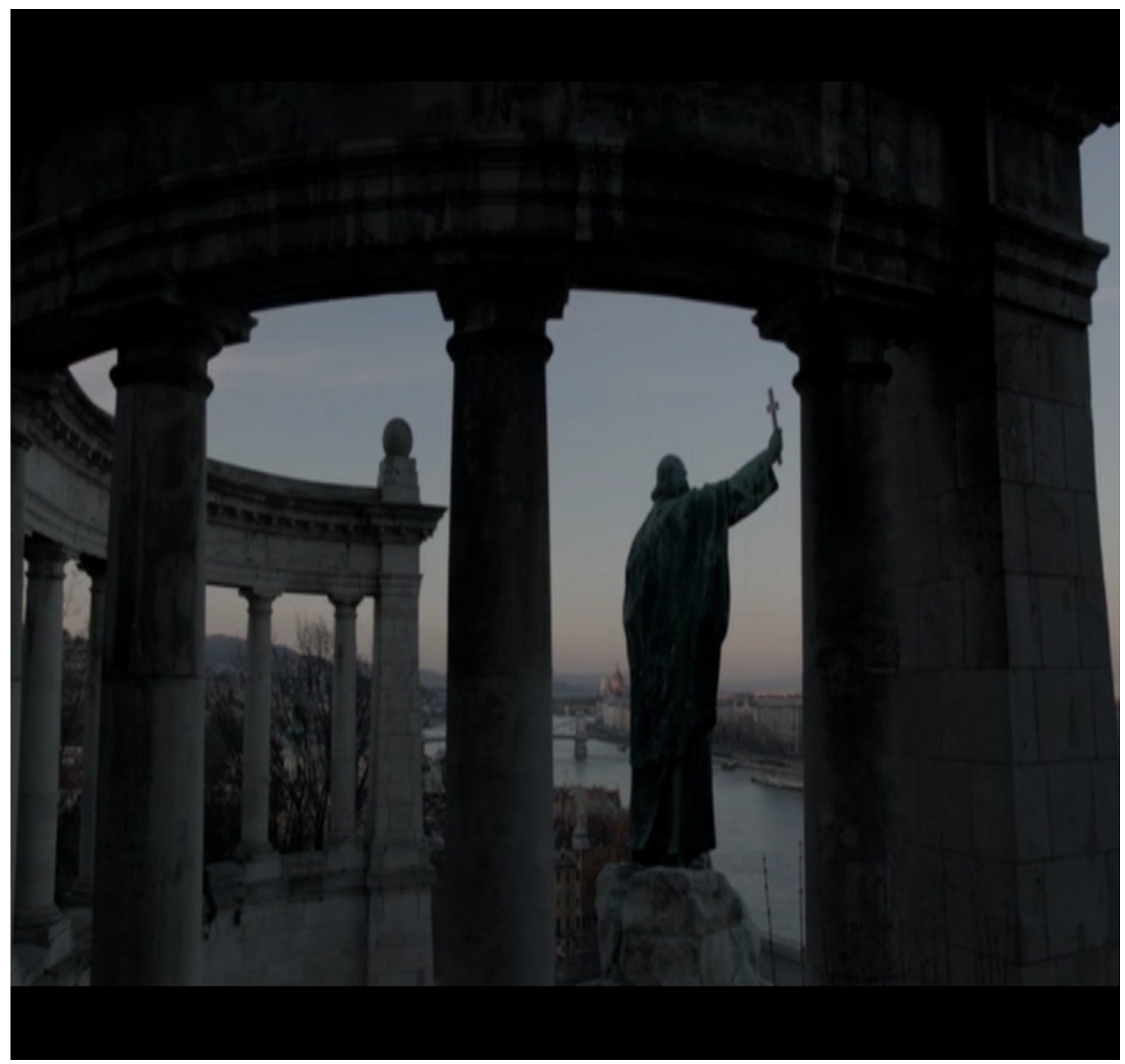

Budapest Noir (Gárdos Éva, 2017)

A filmes helyszínek elemzése a nyolcvanas évektôl kezdődően professzionalizálódik. Az értelmezések alapvetően két hagyományt követnek: az egyik hagyomány a díszlet/lokáció/helyszín és a narráció közötti viszonyra fókuszál, s úgy látja, a lokalizáció az elmondott történetet kifejezó nyelv. A másik hagyomány arra kíváncsi, hogy a helyszínek milyen hatással vannak a nézőkre, milyen érzelmi világokat hoznak múködésbe. Az elsô irányzat Charles és Mirella Jona Affron nevéhez köthetô. Ôk úgy látják, hogy a filmes helyszínek a következó tipológia szerint múködnek: (1) denotáció (denotation) - a helyszín konkrét vonatkozása; (2) punktuáció (punctutation) - a helyszínek a narratíva fordulópontjait jelölik ki; (3) megszépítés (embellishment) - a helyszínek retorikai szerepe, mely a nézó figyelmét a környezetre és a történet narratív szükségszerúségeire irányítja; (4) mívesség (artifice) - a helyszínek metaforikus funkciója, mely illuzórikus és múvi voltukra irányítja a nézó figyelmét (lásd például Fellini Casanova [1976] címú filmjének díszleteit); (5) dizájn-intenzitás (design intensity) - a díszlet olyan sûrített használata, amikor egy adott helyszín a film teljes cselekményének és a narratíva 
fejlôdésének a kulcsa (lásd például az Aranyélet harmadik évadának hetedik részét, mely a behavazott villába összezárt család sorsának alakulása szempontjából sorsdöntô) (Affron - Affron 1995: 36-60.).

Charles Tashiro, részben Affronék megközelítésének kritikáját adva, úgy látta, hogy a filmes díszlet nem csak kiegészítôje a filmes narratívumnak, hanem maga is fejlődik, alakul a film során, illetve a karakterfejlődés, a filmes hatás központi összetevôje. A filmes díszlet ugyanúgy múködik, mint a körülöttünk levô tér, koncentrikus körökbe szerveződik, a szereplők köré zárul. Szerinte a díszletet e koncentrikus körök egymásra épüléseként kell felfognunk: az elsô szeletet a díszlet azon elemei adják, melyek közvetlen érintkezésbe kerülnek a szereplő testével (smink, öltözék, ékszerek stb.), a másodikba tartoznak a tér materiális összetevői (bútorzat, tárgyak), a harmadikba az életterek (lakások, épületek), a negyedikbe a beutazható terek (utcák, körutak, piacterek stb.), az ötödikbe a tájak (térösszefüggések, városok), a hatodikba pedig a kozmikus tér. Tashiro megközelítésében egy film térösszefüggésének legfontosabb eleme az, hogy a rendezô hova tette le a kamerát, mit enged láttatni a nézôvel. Másik kiemelendô összetevő, hogy mennyire datálható a tér, mennyire fejez ki történeti tudást a díszlettel kapcsolatban, hiszen vannak olyan rendezók, akik ahistorikus tereket igyekszenek létrehozni (Tashiro 1998: 6-56.).

Tashiro megközelítése alapozza meg azt a kortárs bevett megközelítést, miszerint a filmes tér immerzív jellegú, mentális vagy haptikus tér, melyben ugyanúgy mozogni tudunk, mint a fizikai valóságban (Bergfelder-Harris-Street 2007: 21-25.). Vagyis a filmes világ sajátos architektúrával rendelkezik, ugyanolyan sajátos építészeti koncepciója van, mint egy városnak, épületnek. Meglátásunk szerint az Afron- és Tashiro-féle tipológiák egyként hasznosíthatóak - fóként olyan filmes univerzumok esetében, melyek erôteljes narratív meghatározottságúak.

A Budapest Noir építészete tehát a dizájnintenzitás gondolata köré épül: nincs a filmes narrációnak olyan eleme, melyben a földrajzi és történeti városnak ne lenne jelentősége. ${ }^{[7]}$ Tashiro koncentrikus körei tehát egy történetileg létezó térszerkezetre, az 1936-os Budapestre vonatkoznak. Illetve ez a térszerkezet érintkezésben van a film noir zsánervárosképével is, azzal, amit Jean-Pierre Esquenazi „la ville noirnak”/ „the noir citynek” nevezett (Esquenazi 2012: 243-247.). A díszletek és helyszínek egyébként is erôsségei Gárdos Éva filmjének ${ }^{[8]}$ : a lokalizációs effektusoknak egyszerre van szinkrón és diakrón jelentéstelítettségük. A helyszínválasztásban a történeti hitelesség igénye erôteljesen jelen van (az Abbázia felirata, a Magyar Királyi Csendốrség által használt vizuális szimbólumok stb. visszakereshetôek, autentikusként azonosíthatóak), ugyanakkor a díszletekben számos olyan megoldás is van, mely egyéníti a szereplôt, életstratégiáit jellemzi. 


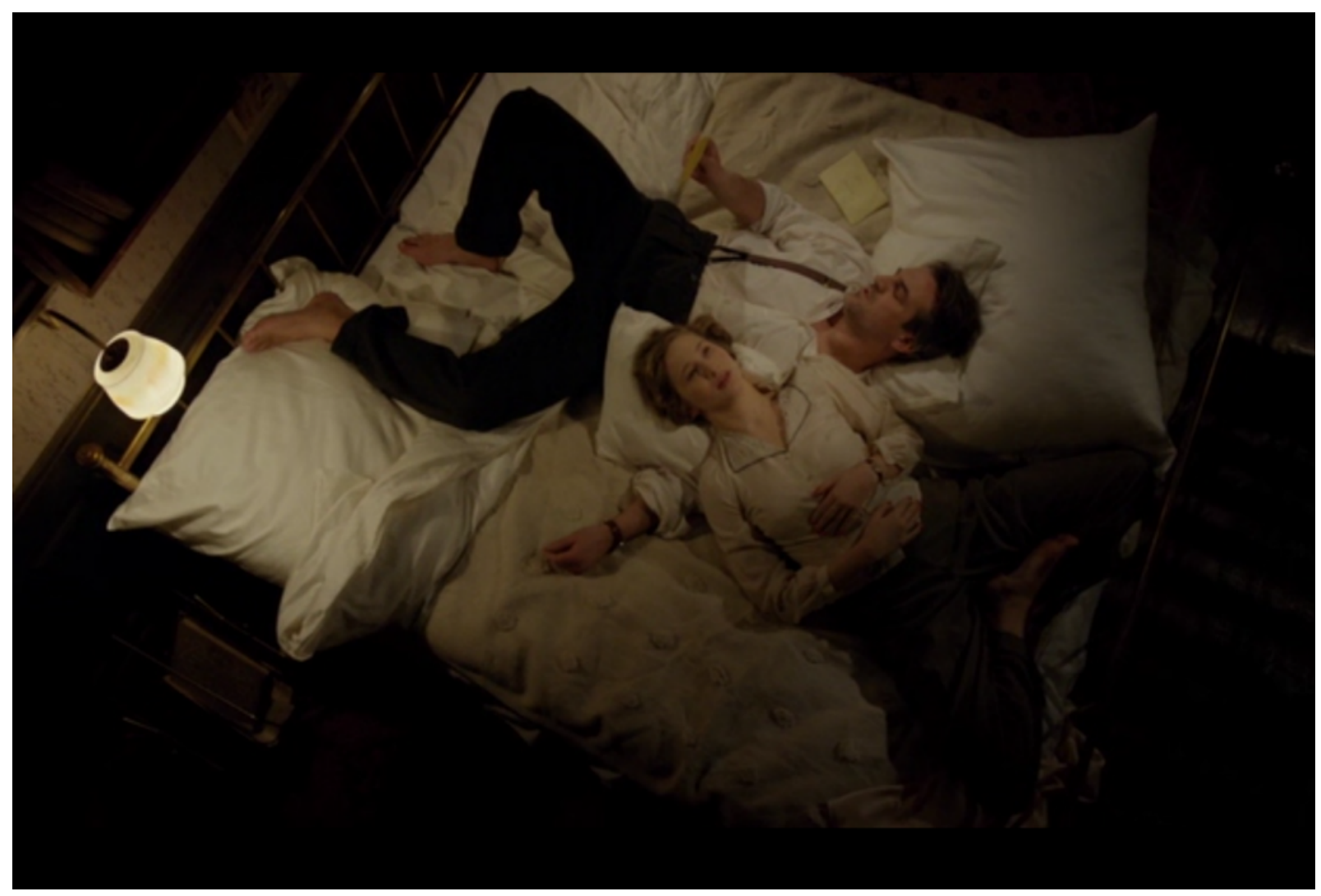

Budapest Noir (Gárdos Éva, 2017)

Szintén Esquenazi állapítja meg, hogy a film noir a városi, publikus tér és nem a privát tér múfaja, e filmek hôsei általában nem rendelkeznek stabil otthonnal, munkájuk miatt szállodákban, ideiglenes szállásokon töltik mindennapjaikat, így otthontalanságuk, a világ bizonytalansága a térhasználatban is kifejezôdik (Esquenazi 2012: 243). A Budapest Noirban Gordonnak van lakása: otthontalanságát inkább az a sajátos nyugtalanság adja, amivel munkáját végzi a szerkesztôségben, a kávézóban, a nyomozási helyszíneken, s önként mond le a privát terek biztonságáról. A film helyszíneit kvantitatív elemzésnek alávetve a következô adatokkal dolgozhatunk: ötvenhat helyszín követi egymást a film során, ezek közül tizenöt privát térben játszódik, tizenöt pedig publikus térben. Privát tér alatt azokat a tereket értjük, melyek csakis a tulajdonosok által, illetve azok engedélyével használhatóak. Publikus téren ez esetben olyan térszerkezeteket értünk, melyek mindenki számára szabadon elérhetôek társadalmi státusztól függetlenül: utcák, pályaudvarok, tömegközlekedési eszközök. A két térforma közötti átmeneti skálán foglalnak helyet a közintézmények terei (csendôrség, szerkesztôség, bonctani intézet), melyek használata státuszhoz és illetékességhez kötött, a városi társiasság és társas élet helyszínei (a kávéháztól az exkluzív látogatottságot feltételezố helyekig, a bokszklubig, a bordélyházig). Értelemszerúen e harmadik kategória huszonhatszor fordul elố a filmben. 


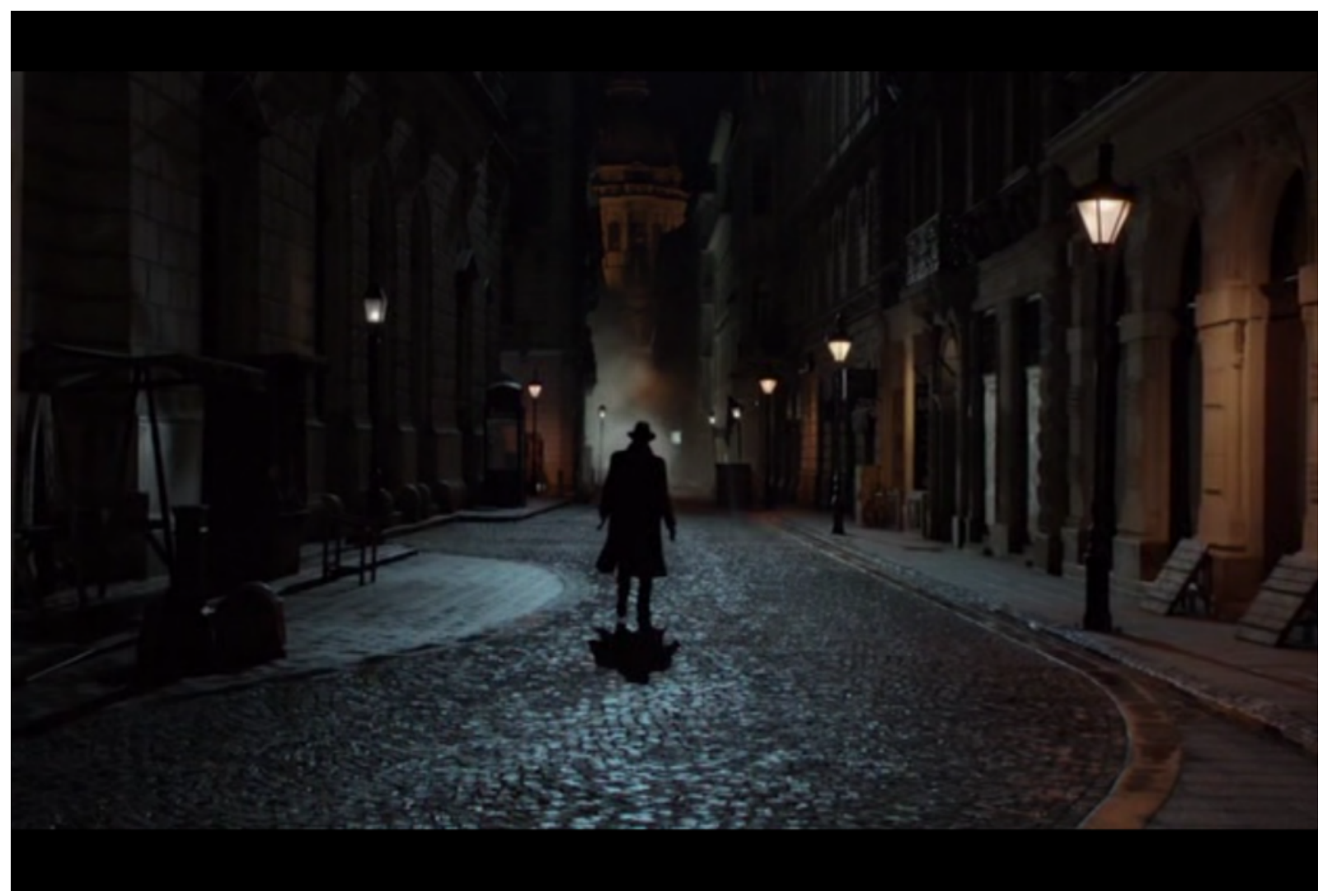

Budapest Noir (Gárdos Éva, 2017) 
Budapest dizájnintenzitását leginkább azzal példázhatjuk, hogy a film keretes szerkezettel rendelkezik, s ezt a keretet a Budapest-referencia teszi lehetôvé: a film fốcím utáni elsô képkockája egy Budapest-panoráma a Gellért-hegy magasságából, a szobor mögül, a félkörívú oszlopcsoport tagolta szerkezetben látjuk felülnézetból a várost, hogy aztán lemenjünk a macskaköves utcára, ahol a főszereplő narrátorhangján elhangzik a várost jellemző mondat: „Budapest, valakinek a halál, valakinek a fények városa." A mondat a tér szimbolikus jelentését értelmezi, a város reprezentációs hozadékát, s a mondat kifejtéseként a nyomozó-újságíró ars poeticáját hallhatjuk. A film noiros klisékbe öltözött szereplố megáll a trafiknál cigarettát venni: ez az a jelenet, mely keretezi a filmet, és lehetôséget nyújt a nappali utcakép megmutatására. A film legutolsó képsora ugyanezt a térszerkezetet és ugyanezt a jelenetet reprodukálja: a különbség annyi, hogy a zsidó származású trafikus kirakatát betörték, elmenni készül, illetve a jelenet ezúttal az esti várost mutatja. A kezdômondatot itt cinikusan kifordítja a forgatókönyvíró: a trafikos panaszára, hogy származása miatt kénytelen elmenekülni Budapestrôl, Gordon ezt válaszoltja: „Ugyan, Kovács, itt nincs mitôl félni, ez Budapest." A mondat a város korrupciós gépezetét és búnhálózatait felvonultató nyomozás után nemcsak a harmincas évek végének történései vonatkozásában cinikus: odaértjük mindazokat a veszélyeket, melyektôl Gordonnak nem volt félnivalója, de párkapcsolatába, átszabott arcába, át nem aludt éjszakáiba kerültek. Az elsố kép Budapestpanorámája megformálásában felidézi azokat a film noirokat, melyek Los Angelest vagy az amerikai búnös városokat mutatták fel ugyanígy, s melyek a kortárs vizuális kultúra számos alkotásába beépített vizuális klisévé váltak (lásd pl. Mulholland Drive vagy a True Detective második évada stb.). Ugyanakkor a kettôs kezdés, a fốcím elôtti és utáni is a film noirokra jellemzô eljárás. 


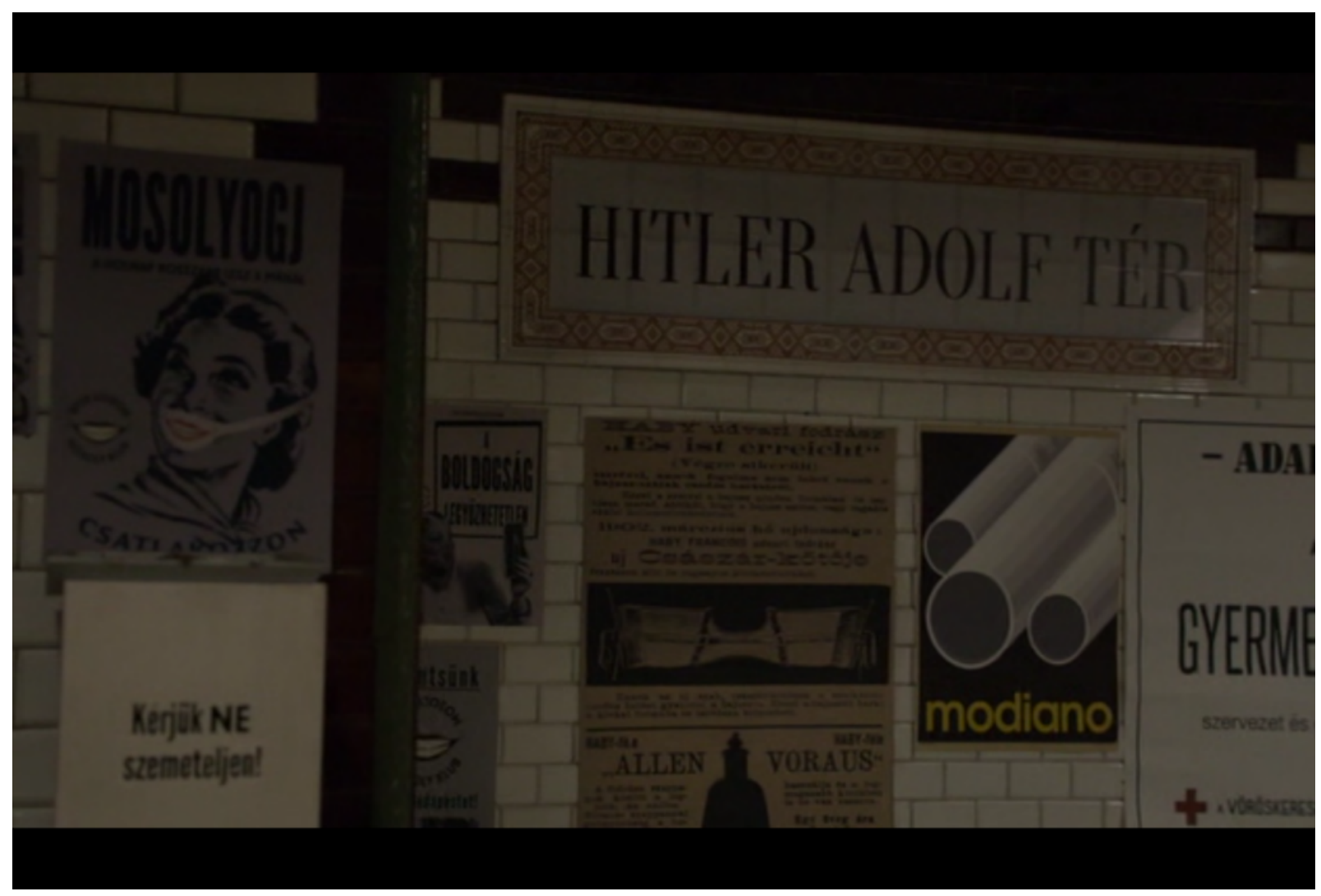

Budapest Noir (Gárdos Éva, 2017)

A térformálás szempontjából nagy szerepe van a tömegközlekedés eszközeinek és tereinek: a film legelsô képkockája a pályaudvart és a vonat füstjét ábrázolja, a beérkező vonatot, a film egyik utolsó jelenete pedig a pályaudvarról kimenô vonatot, mely a biztonságosabb nyugati világ felé viszi a fôhôs élettársát. Az autó versus gyaloglás és tömegközlekedés oppozíció is helyet kap a filmben: Gordon hanyag eleganciával ugrik fel a villamosra, használja a metrót, az autók az állami ellenôrzố rendszer, a korrupt és megfélemlítô hatalom szimbólumai.

A privát terek megjelenítésében két fontos mozzanatot emelnénk ki a regény térszerkezeteinek összefüggésében. Az egyik, hogy Krisztinának a filmben nincsen saját lakása, a regényben viszont láthattuk, hogy a Lövölde téri otthon fontos szerepet játszott, és a két fôszereplő jellembeli különbségét is megjelenítette. Krisztina függetlensége itt az otthontalanság és ebből adódó erôsebb mobilitás által is hangsúlyozódik: a szereplôk táskái méretéből és számából következtetnek úti céljaira. Az elsô jelenet, amikor a szereplő feltúnik, Gordon bérházának lépcsôházában játszódik, s csak cipóje sarkát látjuk. A filmben a magassarkú cipóknek erôteljes szerepe van: Vörös Margó és Krisztina cipôi egymás ellenpontjai. Krisztina magassarkúja dohányszínú, az ideális $5 \mathrm{~cm}$ körüli sarokkal a kiegyensúlyozott jóízlés szimbóluma. 


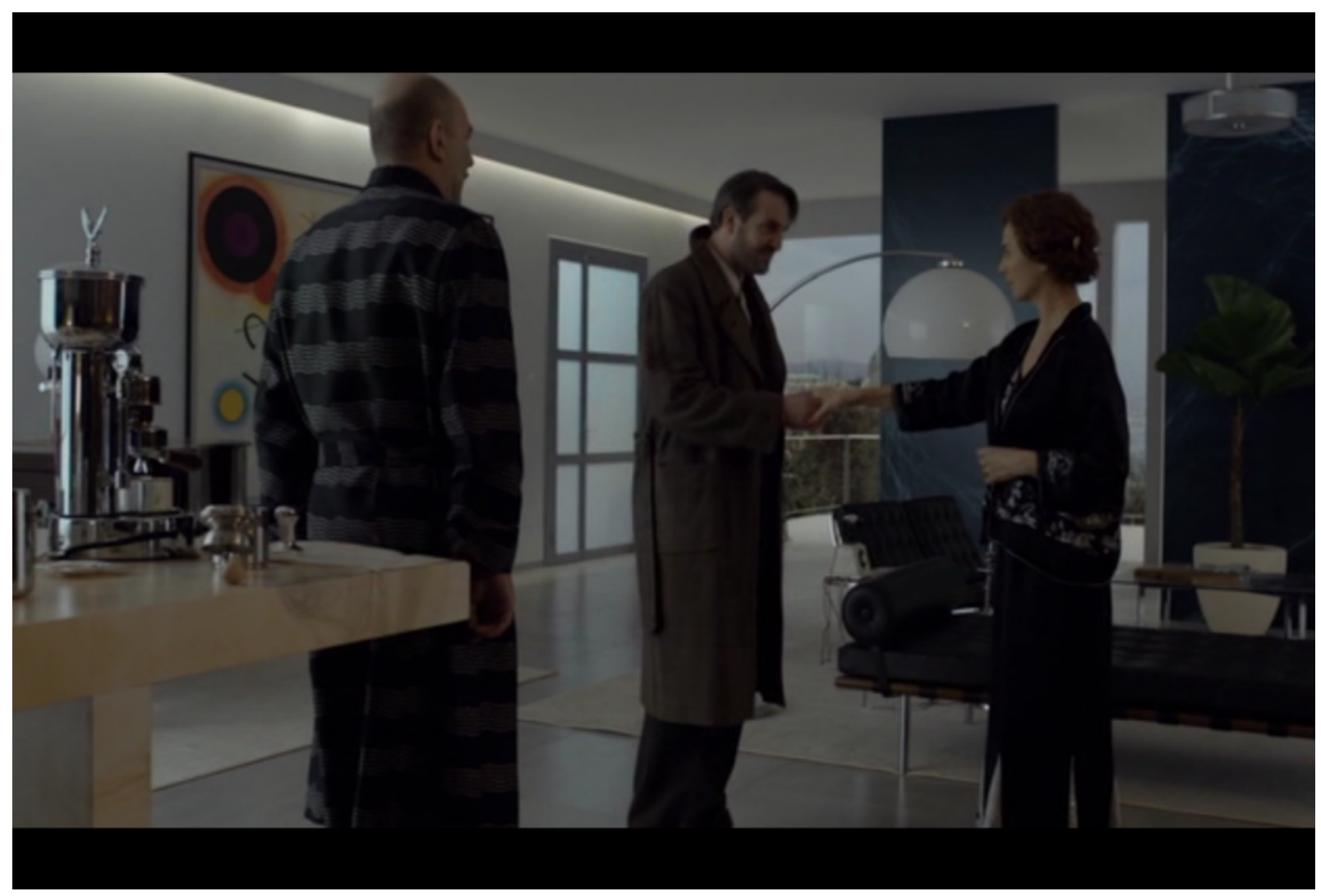

Budapest Noir (Gárdos Éva, 2017)

A másik összefüggés a Szöllósy-villa és annak berendezése. Láthattuk, hogy a regény egy biedermeier környezetbe helyezte el a gazdag zsidó vállalkozót és családját. A film Szöllősy villájának környezetéhez egy prágai korabeli Bauhaus-villa szolgált inspirációul: a villa tele van a korszak fontos dizájntárgyaival és vizuális szimbólumaival, a modernitás dizájnkoncepcióját hangsúlyozza. Csak felsorolásképpen: a Zsolnayk helyére Mies van der Rohe kerül, a falon Vaszilij Vasziljevics Kandinszkij 1923-as Kompozíció III címú festménye látható. A film legmegrázóbb jelenetei azok, amikor ez elôtt a festmény elôtt látjuk a kávékészítés problémáiról értekezni az apát, aki halálba kergette lányát, de gesztusát még mindig jogosnak érzi, hiszen zsidó identitásának következményeitôl védte. A világítótestek közül a zongorán álló Wilhelm Wagenfeld WA24-ese, a nagyformátumú P. and A. Castiglioni Arcója, a bútorzat Mies van der Rohe Barcelona szettje, a kávégép pedig egy Elektra Micro Casa. Ez a lakásbelsô kétségkívül sokkal környezetidegenebb, mint a Kondor Vilmos által megformált. A mívesség kategóriája szerint leírható: kontextusidegensége annak metaforája, ahogyan a zsidó mágnás család Budapesten él, kapcsolatokat épít, gazdasági érdekek hálózatát alakítja ki, ízlése, szokásai azonban eltérnek a város szokásos múködésmódjától. Mindezzel együtt a Szöllôsy-villa a legszebb lakásbelsô, amit valaha magyar filmen láthattunk. A privát tereknél meg kell említenünk az idôsebb Gordon lakását: a virágokkal telerakott, barkácsolt, kacatokkal teli budapesti bérházi lakást, melynek improvizált bája a megszépítés díszletlogikáját közvetíti. 


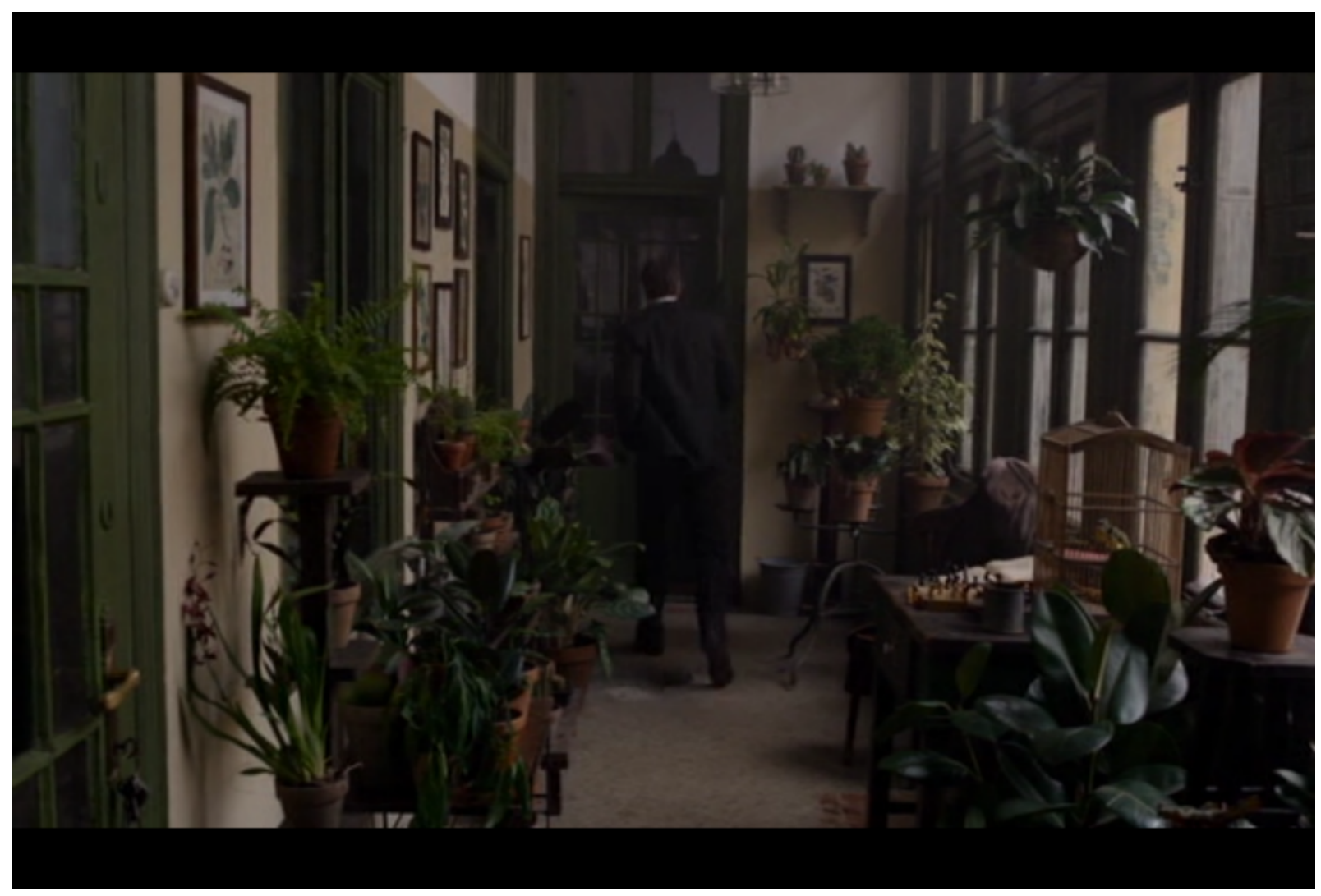

Budapest Noir (Gárdos Éva, 2017)

A film díszletei nagyon szépen írják le Gordon budapesti otthonkeresésének állomásait: az Amerikából hazaköltözött újságíróban ugyan nincsen emigrálási szándék, de folyamatosan a máshonnan érkezett kíváncsiságával és friss tekintetével nézi a várost, nagyvonalúan él benne. Az anakronisztikus nôi élettörténettel rendelkezô Krisztinához fúzôdô kapcsolata megerôsíti a városhoz való kapcsolódásának ezt a végleges ideiglenességét.

\section{Bûnös városok filmen és regényben}

A két szöveg térszerkezeteinek elemzése arra mutat rá, hogy a hard-boiled, illetve a film noir nyelvei koherens nyelvként épülnek fel mindkét médiumban. Kondor Vilmos a hard-boiled hagyományt úgy használja, hogy megkeresi az 1936-os Budapestnek azokat a mozzanatait, amelyek a kemény krimi paraméterei szerint mozgósíthatóak, s kihagy olyan elemeket, amelyek akulturálisak lennének: Gordon élet- és munkaszemlélete kulturális idegenségére folyamatosan utalás történik a regényben. Ez a múlt nem szép múlt, az iránta való vágyakozás nincs jelen a szövegben. Gárdos filmjében viszont már az elsô képkockáktól tudatos az a döntés, hogy ez a Budapest a klasszikus film noirok Los Angeleséhez vagy egyéb bûnös városaihoz lesz hasonlatos: bünössége szép lesz, vonzó és szexi. A terek és környezetek felépítése egyszerre hordozza a vágyakozás és a visszaállítás alakzatait. Az is nyilvánvaló, hogy Kondor regényében a reflexiós folyamat szövegszinten is múködik (lásd például a regénybe beépülô jelöletlen hard-boiled krimi, például Hammettidézeteket), míg Gárdos Éva filmje inkább egy resztoratíve nosztalgikus film noir újraélesztést hoz 
létre. Így természetes, hogy az adaptáció folyamata a kritikai és nosztalgikus beszédmódok örök konfliktusáról fog szólni. Ennek része az is, hogy a regények (elsôsorban az elsô öt), a magyar történelem traumatikus korszakait ragadja meg: harmincas évek, a háború, 1956. A múlt itt nem csupán egzotikus díszlet: a problematizálás egyik fontos összetevôje. Gárdos filmje esetében a történeti díszletek inkább a karakterrajz és a zsánerkonformitás elemei: erôs vizuális szimbólumok, melyeket érdemes a regényhez képesti különbségekbe visszaolvasni.

1. This publication is part of "DETECt. Detecting Transcultural Identity in European Popular Crime Narratives", a project that has received funding from the European Union's Horizon 2020 research and innovation programme under grant agreement No 770151. The publication reflects only the author's view and the Agency and the Commission are not responsible for any use that may be made of the information it contains.

2. Schubert Gusztáv például úgy látja, hogy a hard-boiled krimi meghonosításának strukturális akadályai vannak: a múfaj ugyanis a szabadságról szól (Schubert 2011).

3. Ugyan Kondor Vilmos több nyilatkozatában is visszafogottan ítélte meg az adaptáció sikerességét (Gyárfás 2017; Keresztesi 2017), a recepcióban mégis megfogalmazódott, hogy a hard-boiled és a noir közötti egybeesés miatt leginkább Kondor örülhet a filmnek, hiszen ezzel sikeresen elterjesztette a hard-boiled múfaját Magyarországon (Kránicz 2017).

4. Bahtyin definíciója igencsak enigmatikus: „Kronotoposznak az irodalomban a múvészileg megragadott idô- és térbeli viszonyok lényegbeli kapcsolatait nevezem (szó szerinti fordításban: idô-térbeliség)." (Bahtyin 1974: 753). A fogalom kortárs adaptálhatóságához ld. Bemong et al. 2010.

5. A populáris és a problematizáló irodalom közötti különbségekhez ld. Umberto Eco 1993.

6. A kilencvenes évek Budapestjét megmutató magyar film városképét Varga Balázs így összegzi: „Ahogy nincs egységes városkép, úgy nincs egységes városkép-megmutatás sem. Szabad a vásár, a kilencvenes évek magyar filmjének Budapestje a széttartó rendezői koncepciók felvonulási terepe.” (Varga 2001) Az összegzés óta eltelt lassan két évtizedben a városkép egységesebbé vált, és egységesebbé a róla szóló filmes narráció is: a turistatekintet számára kitalált Budapest lépten-nyomon ott van az HBO produkcióiban vagy az olyan filmekben, mint Xavier Gens 2018-as Legénybúcsú Bt. címmel magyarított Budapest címú filmje. Ez az egynemúsödés, melyet a dróntechnológia terjedése és filmes képalkotásra való hatása is kiváltott, egybeesik a város bekerülésével a turisztikai mainstreambe: mindez azonban egy filmturisztikai elemzés tárgya lehetne. Az összefüggésekhez ld. Irimiás 2015.

7. Ezt a megközelítést, miszerint a film fôszereplôje maga a város, a film sajtóvisszhangja meglehetôsen felerôsítette Ld. például szinhaz.org (2017).

8. A díszletek, a kosztümök és a látvány két olyan szakember munkája, akik a magyar piacról gyakran dolgoznak külföldi produkcióknak: Pater Sparrow a látványtervezó, Andrea Flesch pedig a kosztümtervezô.

\section{Irodalomjegyzék}

- Affron, Charles - Affron, Mirella Jona (1995): Sets in Motion: Art Direction in Film and Narrative. New Brunswick, Rutgers University Press.

- Bahtyin, Mihail (1974): Kronotoposz: idő és tér a regényben. Ford. Moravszky István. Korunk, 1974. június, 753-757.

- Bauman, Zygmunt (2017): Retrotopia. Cambridge, Polity. 
- Bemong, Nele, Pieter Borghart, Michel De Dobbeleer, Kristoffel Demoen, Koen De Temmerman, Bart Keonen (2010): Bakhtin's Theory of the Literary Chronotope: Reflections, Applications, Perspective. Gent, Academia Press.

https://doi.org/10.26530/OAPEN_377572

- Bergfelder, Tim, Harris, Sue, Street, Sraha (2007): Film Architecture and the Transnational Imagination: Set Design in 1930s European Cinema. Amsterdam, Amsterdam University Press. https://doi.org/10.5117/9789053569801

- Boym, Svetlana (2001): The Future of Nostalgia. New York: Basic Books.

- Broe, Dennis (2014): Class, Crime and International Film Noir. Globalizing America's Dark Art. London - New York, Palgrave Macmillan. https://doi.org/10.1057/9781137290144

- Andrew Dickos (2013): Streets with No Name. A History of the Classic American Film Noir. Kentucky, The University Press of Kentucky.

- Eco, Umberto (1993) : Pleurer pour Jenny? In Eco, Umberto: De Superman au Surhomme, Paris, Grasset - Fasquelle, 13-25.

- Esquenazi, Jean-Pierre (2012): Le film noir. Paris, CNRS Éditions.

- Erdmann, Eva (2009): Nationality International: Detective Fiction in the Late Twentieth Century. In Investigating Identities. Questions of Identity in Contemporary International Crime Fiction . Szerk. Krajenbrink, Marieke és Quinn, Kate M. Amsterdam - New York, Rodopi, 11-26. https://doi.org/10.1163/9789042029170_003

- Fay, Jennifer - Nieland, Justus (2010): Film Noir. Hard-Boiled Modernity and the Cultures of Globalization. New York, Routledge. https://doi.org/10.4324/9780203869680

- Grób László (2015): A magyar detektívregény fénykora (1930-1948). Gödöllô, Attraktor.

- Gyárfás Dorka: Számomra ez egy érzelmi szellemvasút volt. Exkluzív interjú Kondor Vilmossal a Budapest noir filmváltozatáról, wmn. URL: https://wmn.hu/kult/47819-szamomra-ez-egyerzelmi-szellemvasut-volt--exkluziv-interju-kondor-vilmossal-a-budapest-noirfilmvaltozatarol; 2019. 10.10.

- Irimiás Anna (2015): Filmturizmus: a filmek és televiziós sorozatok turisztikai szerepének és hatásainak geográfiai vizsgálata. Budapest, Akadémiai.

- Irwin, John T. (2006): Unless the Threat of Death is Behind Them (Hard-Boiled Fiction and Film Noir). Baltimore, The Johns Hopkins University Press.

- Kálai Sándor (2014): Miért intézményesül(t) nehezen a magyar krimi. Korunk, 25.3. 12-17.

- Keresztesi Ferenc: Nincs odáig a Budapest noir filmváltozatáért Kondor Vilmos. 24.hu, URL: https://24.hu/kultura/2017/11/30/nincs-odaig-a-budapest-noir-filmadaptaciojaert-kondorvilmos/; 2019. 10. 10.

- Kondor Vilmos (2008): Budapest noir. Budapest, Agave.

- Kránicz Bence (2017): Kopott kalap, gyưrött ballon. Filmvilág, 60.12. 8-9.

- Lakatos Gabriella (2013): A magyar félbúnfilm (Búnügyi múfajok 1931 és 1944 között). Metropolis, 17.2. 50-66.

- Manchette, Jean-Patrick (2003): Chroniques. Paris, Payot \& Rivages.

- Mayer, Geoff (2007): The Hard-Boiled Influence. In Encyclopedia of Film Noir. Szerk. Mayer, Geoff - McDonnell, Brian. Westport - London, Greenwood Press, 19-47.

- McDonnell, Brian (2007): Film Noir and the City. In Encyclopedia of Film Noir. Szerk. Mayer, 
Geoff - McDonnell, Brian. Westport - London, Greenwood Press, 47-62.

- Mitterand, Henri (1990): Chronotopies romanesques: Germinal. Poétique, 2.21. 89-104.

- Moretti, Franco (1998): Atlas of the European Novel. 1800-1900. London, Verso.

- Moretti, Franco (2005): Graphs, Maps, Trees: Abstract Models for a Literary History. London,

- Verso.

- Philips, Gene D. (2000): Creatures of the Darkness. Raymond Chandler, Detective Fiction, and Film Noir. Kentucky, The University Press of Kentucky.

- Reuter, Yves (1999): Le roman policier. Paris, Nathan.

- Schubert Gusztáv (2011): Noir Posthumus. Búnös Budapest? Filmvilág, 54.11. 35.

- szinhaz.org. A Budapest Noir föszereplöje maga a város. szinhaz.org, URL: https://szinhaz.org/plusz/filmszinhaz/2017/10/27/budapest-noir-foszereploje-maga-varosujabb-kondor-regenyt-filmesitene-meg-gardos-eva/ (2019. 10. 10.)

- Tally (Jr.), Robert T. (2012): Spatiality. London - New York, Routledge.

- Tashiro, Charles S. (1998): Pretty Pictures: Production Design and the History of Film. Austin, University of Texas Press.

- Varga Balázs (2001): Városnézés. A kortárs magyar film Budapestje. Budapesti negyed, URL: http://epa.oszk.hu/00000/00003/00024/varga.html (2019. 10. 10.)

- Warf, Barney and Arias, Santa (2009): The Spatial Turn: Interdisciplinary Perspectives. London New York, Routledge.

- Westphal, Bertrand (2011): Geocriticism: Real and Fictional Spaces. New York, Palgrave Macmillan.

- Williams, Raymond (1973): The Country and the City. Oxford, Oxford University Press.

\section{Filmográfia}

- A törvény nevében 2. (True Detective S2. Nic Pizzolatto, 2015)

- Budapest noir (Gárdos Éva, 2017)

- Legénybúcsú Bt. (Budapest. Xavier Gens, 2018)

- Mulholland Drive - A sötétség útja (Mulholland Dr. David Lynch, 2001) 
(c) Apertúra, 2019. nyár | www.apertura.hu

webcím: https://www.apertura.hu/2019/nyar/kalai-keszeg-a-hard-boiled-krimi-lehetosegei-

magyarorszagon-kondor-vilmos-budapest-noir-gardos-eva-budapest-noir/

https://doi.org/10.31176/apertura.2019.14.4.1

(Q)opertúro 